\title{
In-situ performance evaluation of photovoltaic solar water pumping system in the rural region
}

Ali Omar MAKA, Tariq Nawaz CHAUDHARY, Abdulazez HASAN, Ahmed GATOU

DOI: 10.30464/jmee.2019.3.1.69

Cite this article as:

Maka A. O., N., Chaudhary T. N., Hasan A., Gatou A. In-situ performance evaluation of photovoltaic solar water pumping system in the rural region. Journal of Mechanical and Energy Engineering, Vol. 3(43), No. 1, 2019, pp. 69-76.

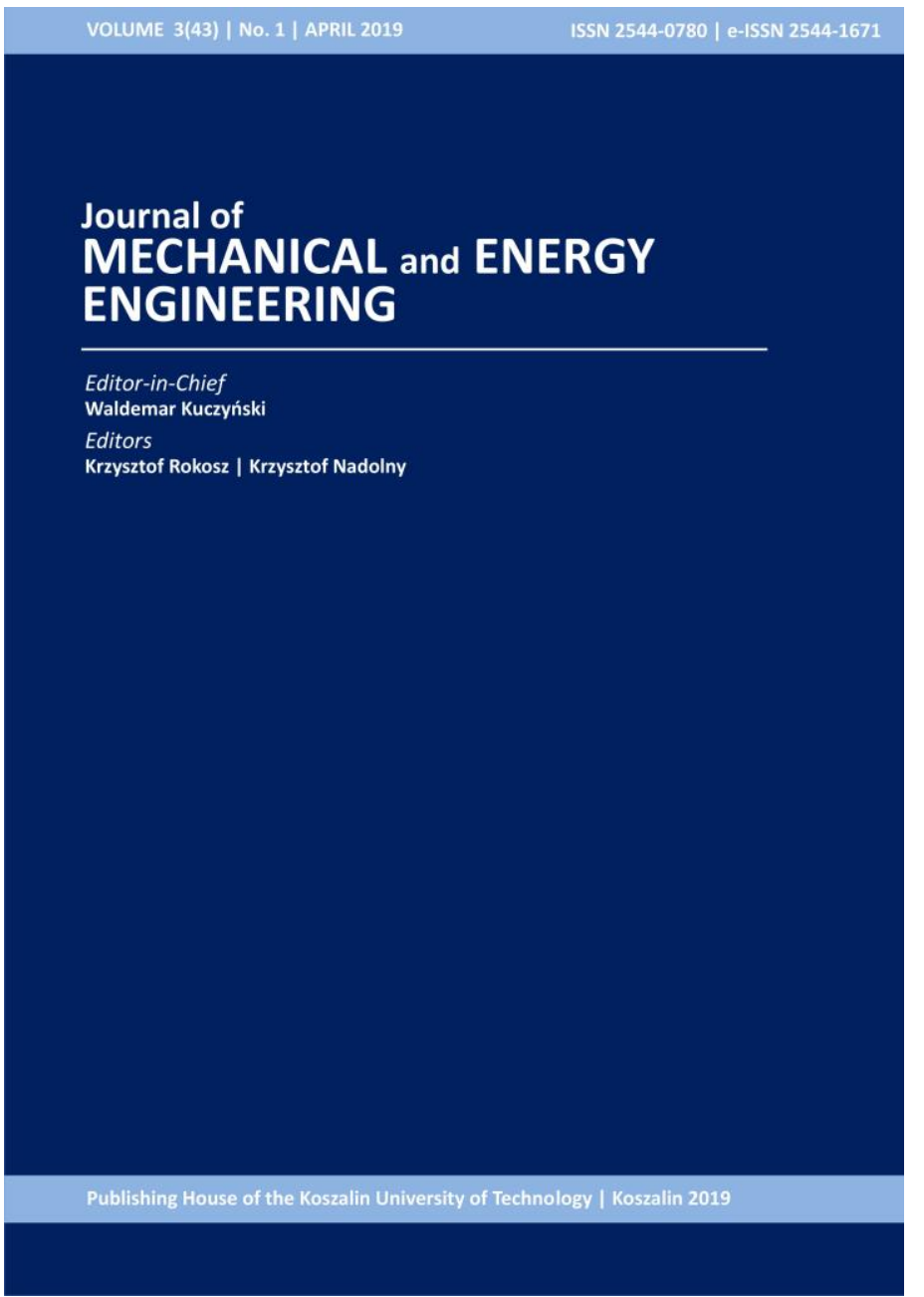

Journal of Mechanical and Energy Engineering

Website: jmee.tu.koszalin.pl

ISSN (Print): 2544-0780

ISSN (Online): 2544-1671

Volume: 3(43)

Number: 1

Year: 2019

Pages: 69-76

\section{Article Info:}

Received 22 February 2019

Accepted 7 March 2019

\section{Open Access}

This article is distributed under the terms of the Creative Commons Attribution 4.0 (CC BY 4.0) International License (http://creativecommons.org/licenses/by/4.0/), which permits unrestricted use, distribution, and reproduction in any medium, provided you give appropriate credit to the original author(s) and the source, provide a link to the Creative Commons license, and indicate if changes were made. 


\title{
IN-SITU PERFORMANCE EVALUATION OF PHOTOVOLTAIC SOLAR WATER PUMPING SYSTEM IN THE RURAL REGION
}

\author{
Ali Omar MAKA ${ }^{1 *}$, Tariq Nawaz CHAUDHARY ${ }^{2}$, Abdulazez HASAN ${ }^{1}$, Ahmed GATOU $^{1}$ \\ ${ }^{1 *}$ Arab Centre for Research and Development of Saharian Communities - Mourzuq, Libya \\ e-mail: maca_4212@yahoo.co.uk \\ ${ }^{2}$ Mechanical Engineering Department, University of Engineering \& Technology Lahore (RCET, Gujranwala)
}

(Received 22 February 2019, Accepted 7 March 2019)

\begin{abstract}
The Photovoltaic solar cells convert the radiant energy from the Sun directly to electricity. Solar photovoltaic systems can help to fulfil the entire energy demands in rural areas by harnessing all the opportunities and potentials. The water is an important element in the life of plants, animals and human being. In this paper, it has been studied that solar energy could be used for water pumping applications such as providing water to rural and remote areas. It is being practiced in south Libya. The data is being collected over two years by measuring the water flow on daily basis at pumping head of $(35 \mathrm{~m})$. In addition, this presents an evaluation of PV system in water pumping and piping systems and estimation of pumping energy cost. The solar pumping systems depend on water flow rate, pumping head and solar irradiance. The system components contain inverter, pump and PV generator. Besides, the effects of the climate and operating conditions on the performance of PV pumping systems has been discussed.
\end{abstract}

Keywords: water pumping, performance analysis, rural region, photovoltaic solar.

\section{INTRODUCTION}

Nowadays the world is moving to explore the clean energy sources and decrease dependent on conventional energy. In spite of solar energy is one of the clean sustainable energy, solar water pumping systems have successful applications in the rural and remote areas. A solar PV array is one of the most significant and rapidly developing renewable energy sources. Whether PV water pump powered by $D C$ current or by $A C$ current; the most commonly employed system consists of $A C$ pump and photovoltaic inverter $[1,2]$.

The water is an essential part to continue the existence of human being, animals and plants. In Libya, the initial project in the field of water pumping was launched in 1983, where a PV pumping system was used to pump the water for irrigation in "ElAgailat" city. Subsequent, another project performed in "Godaem" city west of Tripoli [3]. Presently, there are many PV water pumping systems implemented in the country. The future plan is to install around 100
PV systems to pump water for irrigation of date trees in the desert of Libya [3, 4].

The water pumping is considered as one of the best PV applications to pump water for human and livestock in rural areas. The water pumping projects installed about $35 \mathrm{PV}$ systems with a total peak power of $96 \mathrm{~kW}_{\mathrm{p}}$. The total estimated peak power for this application is $110 \mathrm{~kW}_{\mathrm{p}}$ [4]. Experimental setup of solar energy has been installed in the Saharian environment, for scientific research purpose, the system applied for water pumping. Furthermore, there is four PV water pumping systems have been installed in the south region of Libya. The PV modules are of a Polycrystalline type and the peak power generated from each module $75 \mathrm{~W}_{\mathrm{p}}$.

The PV solar pumping system performance with a maximum power point tracking (MPPT) is evaluated with and without battery storage [5]. The water pumping system with battery storage can operate at a specific speed and resulted in the efficiency improvement of the Permanent Magnet DC (PMDC) motors. 
The experiments were performed on solar photovoltaic water pumping system for four different heads on clear sunshine days. The best efficiency was found at 10 bar for helical rotor submersible pump. The effect of the solar radiation was also investigated. The irradiance ranges $400-800 \mathrm{~W} / \mathrm{m}^{2}$ were suggested for the system upsize as more than $60 \%$ of total solar energy falls in this range [6].

The significance of this work is an abundance of mean daily sunlight radiation in the study region. The direct solar irradiance ranged between1700$2800 \mathrm{KWh} / \mathrm{m}^{2} /$ annually. In Libya, the daily average of solar radiation on a horizontal is $7 \mathrm{kWh} / \mathrm{m}^{2} /$ day in the coastal region and $8 \mathrm{kwh} / \mathrm{m}^{2} /$ day in the southern region, over the year $[4,7]$

Mourzuq is oasis located in southern region of Libya; it is altitude at $456 \mathrm{~m}$ above sea level; latitude $25.55^{\circ} \mathrm{S}$, and longitude $13.56^{\circ} \mathrm{N}$. Desert region receives intensive solar radiation every day that encourages to adopt solar energy. Solar irradiance is the amount of solar energy received by or projected onto a specific surface and solar radiation is the energy $\left(\mathrm{kW} / \mathrm{m}^{2}\right)$ from the Sun that reaches the Earth. Longterm variation of global solar radiation on a horizontal. To our knowledge, there is a limited number of publications and research conducted in that particular region.

In this paper, we present a performance analysis of a solar water pump system in rural areas. The water flow rate determines as a function of solar intensity and the total pumping head. Also, the prediction of system annual running cost. It is significant in order to assess who can utilise such technology of PV to inhabitant who are living in such an environment, which is rich by the natural resource.

\section{MEASUREMENT PROCEDURE}

The solar photovoltaic system installed for water pumping is described below. The water flow meter fitted at end pipe to measure the water produce during working hours. The system performance is evaluated by recording data over two years. The weather data for the region of solar radiation and environment temperature is also considered in this study to evaluate the performance. This platform of experimental work gives an overview, which helps to assess for long-term operating performance. In addition, the key emphasis on this study was to assess solar water pump performance by measuring solar intensity, pumping head, and an average of daylight hours.

\subsection{Photovoltaic Modules descriptions}

The PV cells are made from semiconductor materials, which convert sunlight energy directly into electrical energy. PV cells are manufactured from single crystalline silicon in high efficiency. The average efficiency of a polycrystalline PV cell is 20-
25\% [8]. The sunlight which contains energy photons incident on the solar cells, which consist of P-N semiconductor material to generate electron-hole pair and the accumulated charges on the opposite plate resulting in the generation of electricity.

The system consists of 42 modules polycrystalline; each PV module generates $75 \mathrm{~W}$ at peak power. Open short circuits and maximum power current of the module is $4.7 \mathrm{~A}$ and $4.3 \mathrm{~A}$ respectively. Whereas, Open circuit and maximum power voltage is $18 \mathrm{~V}$ and $17 \mathrm{~V}$, respectively. The total module power is $3150 \mathrm{Wp}$. Every four modules are connecting in series that represent the array and the tilted angle is $40^{\circ}$ oriented to the south for all the modules.

The load matching factors various from season to season. To maximise the performance of Photovoltaic water pump system, the operation of the load must be close to maximum PV array power throughout the day $[9,10]$. The number of the PV modules, required to generate the desired power, are determined as:

$$
\mathrm{M}_{\text {No. }}=\frac{\mathrm{P}_{\text {total }}}{\mathrm{P}_{\mathrm{Sig}}},
$$

Where $M_{N o}$.is the number of modules needed, $P_{\text {total }}$ the total power generated and $P_{\text {sig }}$ the power of a single module. The PV modules can be designed to produce different amount of power and the total peak power depends on PV modules size, the power needed and climate of site location.

Parameters that are very important on the PV characteristics namely short-circuit current $\left(I_{\mathrm{sc}}\right)$, opencircuit voltage $\left(V_{\mathrm{oc}}\right)$ and the maximum power point $\left(I_{\max }, V_{\max }\right)$. PV module efficiency is defined as the ratio of the maximum output power to solar power radiation received by the cell surface.

$$
\eta_{m}=\frac{P_{\max }}{P_{i n}},
$$

where the $P_{\max }$ is the maximum module power $P_{\max }=$ $I_{\max } \times V_{\max }$ and $P_{\text {in }}$ is the incident solar radiation.

\subsection{Inverter and Controller Switch}

The benefit of the inverter is to convert $D C$ current produced from $\mathrm{PV}$ array to $A C$ current, in order to power the motor pump in down well. The inverter consists of the electrical circuits and receives the power from PV modules. It also ensures protection against temporary electric disturbances such as short circuits, overload and low voltage [10, 11]. Inverter efficiency is about 93\% and can be expressed by equation (3). Where $P_{\text {in }}$ is the power input and $P_{\text {out }}$ is the power output.

$$
\eta_{\text {invertor }}=\frac{P_{\text {out }}}{P_{\text {in }}} .
$$

The inverter can be equipped with a data logger system in order to measure and monitor power, 
intensity, frequency, flow rate, temperature and pressure. The data can be monitored on screen or recorded in memory throughout the year [11]. The Controller switch is used to start up and shutdown the pump. A controller alters the output of the PV modules to meet the requirements of the pump. Table 1 summaries the specification of the inverter.

Tab. 1. Inverter specification

\begin{tabular}{ll}
\hline Inverter Type & TSP 4000 \\
\hline Input voltage & $210-340$ V.DC \\
\hline Maximum operating voltage & $340 \mathrm{~V}$ \\
\hline Maximum operating current & $17 \mathrm{~A}$ \\
\hline
\end{tabular}

\section{RESULTS AND DISCUSSION}

Performance of PV solar pumping system has been assessed at the normal operating environment. It is important to understand the effects of different parameters on the performance behaviour.

\subsection{Pump Performance Analysis}

In the analysis of the operating performance of a photovoltaic pumping system, mathematical equations from (5-8) are used. In order to investigate PV pump performance, the elements will be discussed are as follows;

- solar water pumping,

- piping system,

- pumping energy cost.

Electric energy is a prime mover in converting pump mechanical energy to work. Thus, the work is needed to lift a certain amount of water from depth to the surface. Water pumping systems are used instead of internal combustion engines in many rural and remote areas. The utilization of solar water pump in developing countries is considered as a practical solution to meet the water needs of the inhabitant. The technology of solar water pumping is commercially available with less maintenance cost, high reliability and environmental friendly.

The system of solar water pumping has been installed in a desert environment, which is designed to produce $50 \mathrm{~m}^{3}$ of water daily at the head of $50 \mathrm{~m}$.

In solar water pumping the load is Electrical Submersible Pump (ESP), which is a centrifugal pump type. The motor power $2200 \mathrm{~W}$, which is equivalent to three horsepower and service voltage $160 \mathrm{~V}$. The nominal speed of the motor is 3480rpm and Frequency $60 \mathrm{~Hz}$. Well deep is $72 \mathrm{~m}$, water top service $7 \mathrm{~m}$, pump set up at $35 \mathrm{~m}$ deep, Figure-1 shows the application of water pump in the rural region. Total dynamic head $(H)$ for a pump is the sum of the vertical lift and friction loss (0.67) in the pipe. The equation (4) [12-14] is used to define the magnitude of $(H)$ :

$$
H=h_{t s}+h_{f},
$$

where $h_{\mathrm{ts}}$ is the total static head and $h_{\mathrm{f}}$ is the pressure head loss due to friction in the pipeline.

Fig. 1 application of PV system for water pumping in a rural region. The data of daily water flow is collected hourly and along the two consecutive years. The water flow rate is significantly high during the summer season, in contrast, to flow in the other seasons. Based on that a high abundance of solar irradiance through months from April to September.
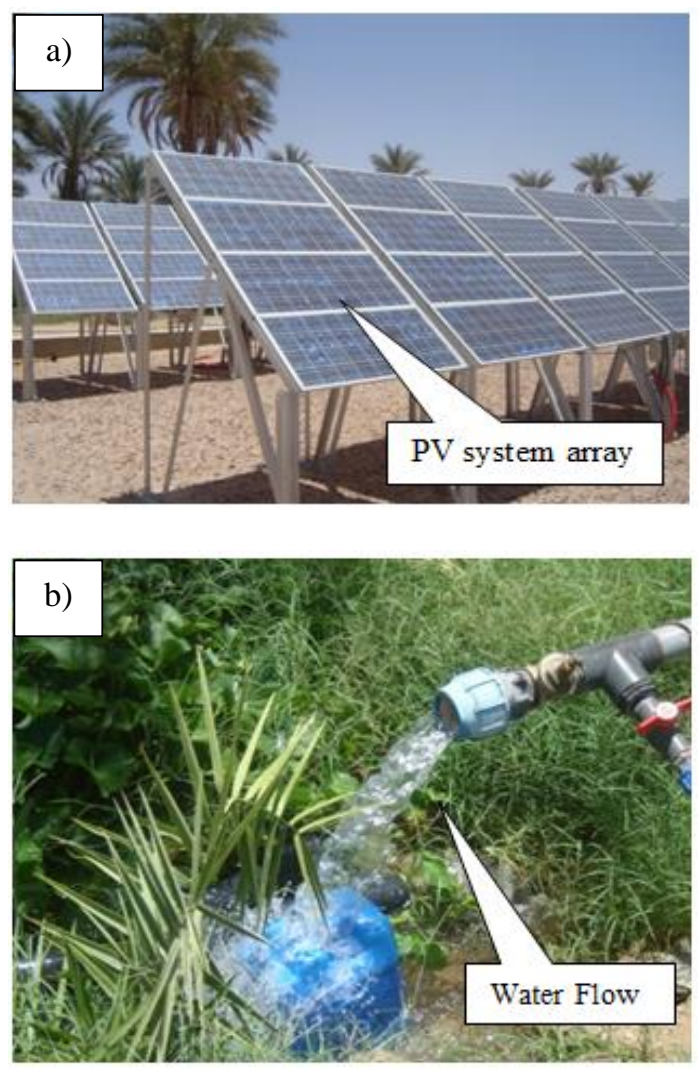

Fig. 1. Application of PV system for water pumping in a rural region.

Figure 2 shows the comparison between the water flow rates, which were measured hourly on the $3^{\text {rd }}$ of June and the $10^{\text {th }}$ of December. In June, the sunlight is present more than 13 hours and the peak of the flow at midday. While at $10^{\text {th }}$ of December approximately 10 hours of daylight in the winter season. In addition, as depicted in the morning the values of solar intensity lower, so the corresponding water flow rates lower. While in the noon-time, the values of solar intensity are higher which results in higher water flow rates. In order to see the way of performance for different PV solar system, so Table 2. detailed some installation of PV solar pumping. 
Tab. 2. Summarised performance evaluation of PV water pumping system application

\begin{tabular}{ccccc}
\hline Authors & Country & PV power $(\mathrm{Wp})$ & Head $(\mathrm{m})$ & Flow rate $\left(\mathrm{m}^{3} /\right.$ day $)$ \\
\hline Odeh et.al. [15] & Jordan & 4500 & 24 & 30 to 100 \\
\hline Hamza \& Taha [16] & Sudan & 1100 & 24 & 32 \\
\hline A.Ghoneim p [17] & Kuwait & 210 & 15 & 12 \\
\hline
\end{tabular}

Fig. 3 illustrates the average water flow in each month of the year 2009 and 2010. As illustrated, the peak of water discharge during June, due to the high solar intensity and long daylight hours. Fig. 4 showed average daylight duration for different months of the year. The maximum daylight duration 13 hours in June and minimum 10 hours in December.

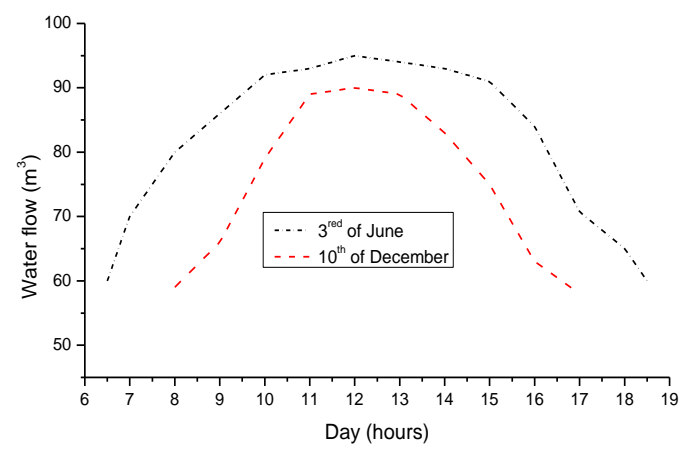

Fig. 2. Daily water flow rate through daylight hours

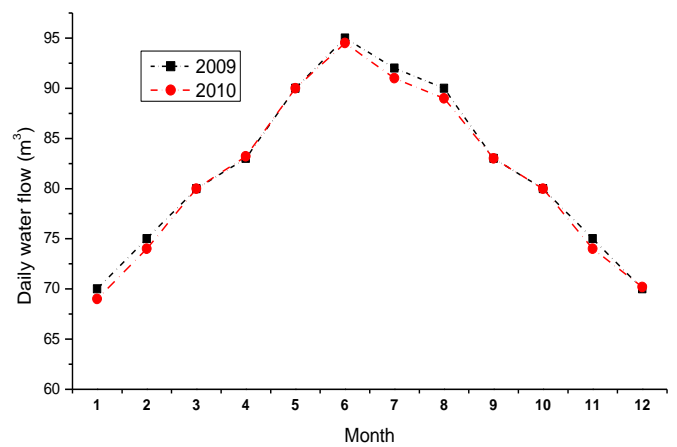

Fig. 3. The average of water flow versus periods of the year 2009 and 2010

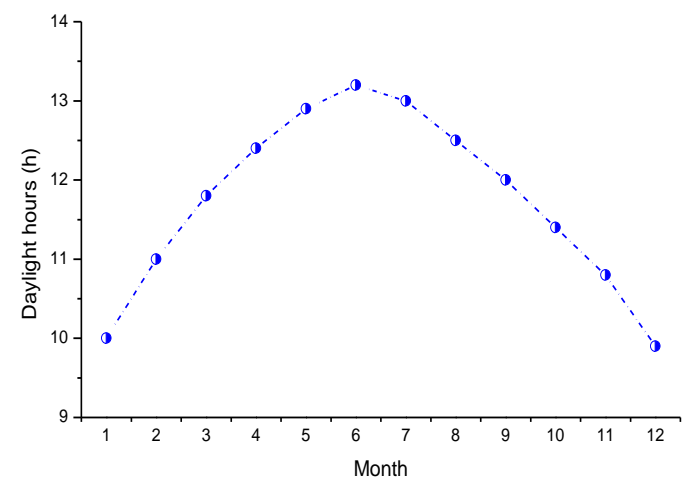

Fig. 4. Average of daylight hours
The ambient temperature varies along the year which can be seen from Fig. 5. The maximum ambient temperature occurs during summer season which leads to greater variation in solar radiation, as shown in Fig. 6. A high solar radiation results in larger power generation from the models especially in summer season because of longer period of sunshine. It is important to mention that, higher environment temperature, of course, will lead to a reduction in the efficiency of the cells.

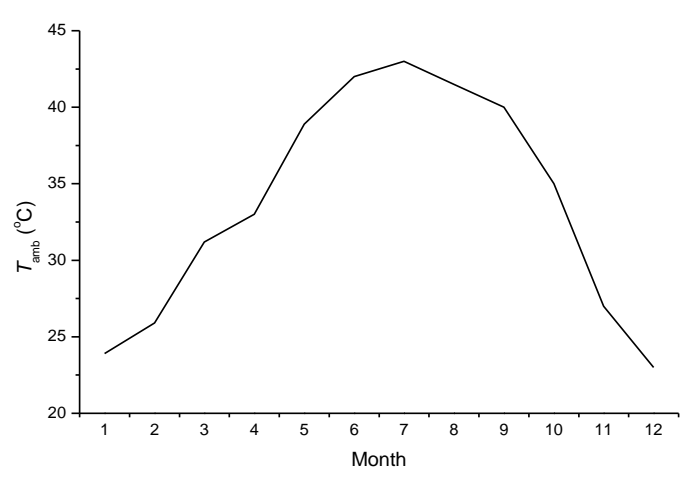

Fig. 5. Average monthly ambient temperature variation for Mourzuq city

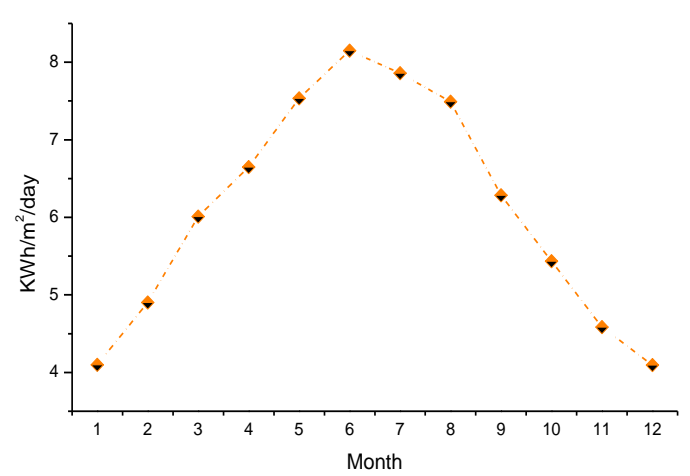

Fig. 6. The annual solar radiation variation of Mourzuq city

Normally, the pumps categorized based on fundamentals of operation, so it divided into two parts:

- positive displacement pumps,

- dynamic pumps.

The positive displacement pumps function via forcing a fixed volume of liquid from the inlet pressure section of the pump to the discharge zone of 
the pump. The dynamic pumps function by developing a high velocity, and fluid pressure in a diffusion of the flow path. It is important to mention the axial flow pumps and centrifugal pumps are dynamic pumps [18].

Moreover, in the winter season the sun lying directly on the tropic of Capricorn. The sun deviates to the south, which results in the change of tilt angle from season to season. The optimum solution is installing a tracker system. The combined characteristics of the pump and motor of the solar pumping system determined by calculating head, discharge and efficiency. The discharge is calculated as;

$$
Q=\frac{\operatorname{Dis}_{(\text {water })}}{D i s_{(\text {time })}},
$$

where $Q$ is the flow rates, $\left(D i s_{\text {water }}\right)$ is discharge water and $\left(D i s_{\text {time }}\right)$ is discharge time. One of the main characteristics of the pumping systems is to consider the capacity in terms of daily hydraulic energy which can be defined as [13]:

$$
H y_{\text {output }}=Q \cdot \rho \cdot H \cdot g \text {, }
$$

where $H y_{\text {output }}$ is the hydraulic output $(W), Q$ is the flow rate $\left(\mathrm{m}^{3} / \mathrm{s}\right)$, is the density of water $\left(\mathrm{kg} / \mathrm{m}^{3}\right), H$ is the water head $(m)$ and $g$ is gravity $\left(\mathrm{m}^{2} / \mathrm{s}\right)$.

The efficiency of the pump is defined as the ratio of hydraulic output to the electric input from the solar irradiance. The typical efficiency of the pump is $56 \%$. The equation (7) is used to find the efficiency [19].

$$
\eta_{\text {ipump }}=\frac{H y_{(\text {outpui) }}}{E l_{(\text {imput) }}} x 100,
$$

where $\eta_{\text {pump }}$ is the pump efficiency and $E l_{\text {(input) }}$ is the electrical input.

Electric power is the power absorbed by the pump, which is calculated by multiplying the voltage with the current. The estimated solar power generation is calculated as;

$$
S P_{(\text {generate })}=\frac{D W \cdot H}{D N I . \eta_{\text {pump }}},
$$

where $S P_{\text {(generate) }}$ is the Solar power generation $(\mathrm{kWp})$, $D W$ is daily water requirement $\left(\mathrm{m}^{3}\right)$ and $D N I$ is direct normal daily irradiation $\left(\mathrm{kW} / \mathrm{m}^{2}\right)$.

The main consideration to quantifying pumped flow is the incident solar intensity and it is availability period. In addition, other parameters are taken into the account in determined the water flow rate is the pump head and the size of the PV array [13]. The efficiency solar centrifugal pump is a function of pumping head, flow rate and solar irradiance. Therefore, pumping system performance is proportional to pump head and incident irradiance. Figure 2 shows a typical performance of the solar pump on a daily basis.

\subsection{Piping System}

The most important considerations in the design of the piping system are the selection of appropriate pipe size, flow rate required, and the distance between the water source and the outlet [9]. The different types of pipes are available, and the most common material used to make these pipes is High Density Poly Ethylene (HDPE) along with galvanized steel and copper. The total system head will quantify the pump size for each pipe size. In order to determine the minimum pipe size; the most important parameter is the required pressure at the outlet. The estimated water flow of this particular system is $50 \mathrm{~m}^{3}$ and 2 inched diameters of the pipe. The equation (9) [12] is used to detriment the optimum pipe diameter $(D)$ :

$$
D=\sqrt{Q^{*} 0.082},
$$

The energy losses essentially depend on flow rate, fluid type, pipe diameter, length and roughness. While, in long pipes, these losses are typically quite small, in contrast with the loss due to friction. However, in short pipes, these losses are similar to friction losses. The small losses are due to the loss of energy in bends and at the exit from the pipe [1]. The nominal volumetric flow rate of water in the good section of the system is about 22 gallons per minute. In order to determine whether the flow in this section of the system is in the turbulent or laminar regime, it is necessary to define the dimensionless Reynolds number with respect to the diameter of the pipe.

\subsection{Pumping Energy Cost}

Estimation of solar pumping energy cost depends on the conditions at the site. Factors affecting the energy cost are desired flow rate and system head. Hence, the energy cost to pump water is given by equation (10) [12]. This will determine the number of solar modules needed, and pump horsepower. The system is designed to provide water for pumping against the total head.

$$
\operatorname{Energy}_{(\cos t)}=\left(\frac{D W}{Q}\right) \cdot H p \cdot E l_{(\cos t)} \cdot 4 \cdot 5,
$$

where Energy (Cost) is Energy cost (\$), DW the daily water requirement $\left(\mathrm{m}^{3}\right), Q$ is the flow rate $(\mathrm{gpm})$. The $H \mathrm{p}$ is Pump size by horsepower. $E l_{\text {(cost) is an }}$ electricity cost assumed $=(\$ 0.06 / \mathrm{kWh})$ and 4.5 is the unit conversions.

Approximately 22 gallons per minute of water are required for minimum water flow. Consequently, the estimated pump energy cost is $\$ 1.84 /$ daily, and $\$ 0.00368 / \mathrm{m}^{3}$. The monthly and annual costs of the systems are turned up to $\$ 54$ and $\$ 650$, respectively. The total estimated cost of the installed system is $\$ 13.000$ and service lifetime within 20 years. The Fig. 7 illustrates the estimated cost. 


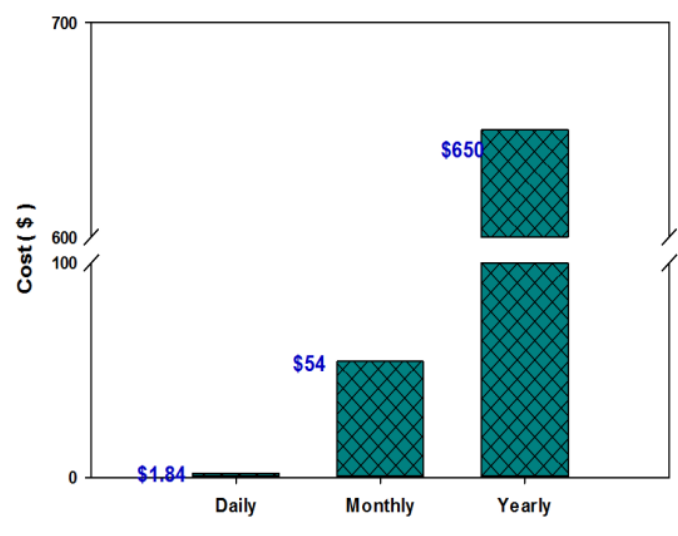

Fig. 7. Estimated cost versus different periods of the year

\section{EFFECTS OF THE ENVIRONMENT ON PV SYSTEM PERFORMANCE}

The climate of the Libyan Desert is a dry hot and cold in summer and winter, respectively. It is rarely rainy. But the western wind and "Gebli" is local wind prevailing in the region, usually carrying dust particles in the spring season. The PV installation in the desert region requires regular cleaning to maintain optimum performance [20]. However, the accumulations of dirt objects on the solar module have a significant impact on output power and overall system efficiency. An increase of ambient temperature cause increase in short circuits current and significant decrease in open circuit voltages, eventually the conversion efficiency of the module decreases [21].

Libya is located in the middle of North Africa with $88 \%$ of its area consider to be desert; the South is located in the Sahara desert where there is a high potential of solar energy which can be used to generate electricity by solar energy conversion systems such as PV [4, 22, 23].

The amount of solar radiation is the main factor that influences the PV module output. Therefore, the module output is proportional to the irradiance level. The Incidence of Solar energy increased on Earth surface if the tilt angle oriented to the South, and it decreases towards the North. In addition, the solar energy magnitude, the location, latitude, annual season, amount of cloud in sky and altitude has an effect on the solar energy

The performance of the PV module is influenced by several parameters such as ambient temperature, humidity, rain, cloud and dust. In a desert environment, the operational performance impeded via sand particles accumulation on the surface and higher ambient temperature. An appropriate tilted angle might reduce dust accumulation. Furthermore, during the installation of the solar array, the bulk of sunlight through diurnal hours should be taken into account, which means consideration before/after midday. The implementation of a maximum power point tracker helps to tackle the situation. Tracking can be very effective for increasing energy production throughout the year, it can be up to 50\% during some months [10]. Due to the difficulty of tracking mechanisms and their associated controls, in water pumps, the stationary system is installed, and oriented to the South. Hence, the peak of the solar irradiance gained in the midday $[21,24]$.

Performance PV array practically depends on climatic conditions, operating and design parameters. The Sun lying change from season to another, which might need to change the tilt angle from season to other or install tracker system. Therefore, environment sunlight intensity is lower in December and higher in summer period [24].

For analysis purposes, the solar radiation arrives at the Earth's atmosphere, then decomposed into different ways. In the uses of Photovoltaic application, the most important ray is the horizontal global irradiance, which determined the amount of irradiance that received by the surface of the flat horizontal $\left(\mathrm{W} / \mathrm{m}^{2}\right)$ [18].

\section{CONCLUSIONS}

Investigation of performance analysis of PV pumping system in rural areas has been carried out. It is concluded from the operation that the PV systems are proven to be technically feasible and appropriate for water pumping. In addition, the efficiency of the pump system found to be $56 \%$. and pump energy cost predicted $\$ 1.84$ per day. The estimated yearly saving was about $\$ 650$. It can be installed in many places for water to use in agriculture or electricity generation.

The technology of PV is beneficial to utilise in rural applications. The most important lessons were learnt are high reliability and cost-effectiveness of PV pumping system. The system has less maintenance, long life cycle, and no emission of harmful gases. It's important to adopts such as renewable energy will be a good choice, so further recommended work is performance optimisation in different environmental conditions.

\section{Acknowledgements}

The authors would like to express grateful thanks to all staff in the Arab Centre for Research and Development of Saharian Communities, Mourzuq, Libya. for their assistant and encourage to the success of this work.

\section{Nomenclature}

\begin{tabular}{|c|c|}
\hline \multicolumn{2}{|c|}{ Symbols } \\
\hline$D$ & - pipe diameter \\
\hline$D W$ & - daily water requirement $\left(\mathrm{m}^{3}\right)$ \\
\hline$D N I$ & - direct normal radiation $\left(\mathrm{kW} / \mathrm{m}^{2}\right)$ \\
\hline$H$ & $-\operatorname{Head}(m)$ \\
\hline Hy $y_{\text {output }}$ & - hydraulic output (W) \\
\hline
\end{tabular}




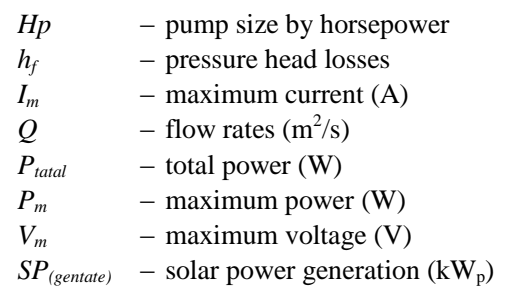

Greek letters

$$
\begin{array}{ll}
\rho & - \text { density }\left(\mathrm{kg} / \mathrm{m}^{2}\right) \\
\eta_{\text {pump }} & - \text { pump efficiency } \\
\eta_{\text {invertor }} & - \text { inverter efficiency } \\
\eta_{m} & - \text { module efficiency } \\
\mathrm{g} & - \text { gravity }\left(\mathrm{m}^{2} / \mathrm{s}\right)
\end{array}
$$

\section{Acronyms}

$\begin{array}{ll}\text { AC } & \text { - Alternating current } \\ \text { DC } & \text { - Direct current } \\ \text { ESP } & \text { - Electrical submersible pump } \\ \text { El(cost) } & \text { - Electricity cost } \\ \text { Dis(water }- \text { discharge water } \\ \text { Dis(time) } & \text { - discharge time } \\ \text { El(input) } & \text { - electrical input } \\ \text { HDPE } & \text { - High density polyethene }\end{array}$

\section{REFERENCES}

1. Reza, K.M., S. Das, and Z.H.J.D.U.J.o.S. Mahmood, Performance Analysis of a PV Pump Harvesting Rain Water in the Drought Prone Area of Bangladesh. 2012. 60(1): p. 37-41.

2. Roy, R.B.J.C.J.o.E. and E. Engineering, Design and performance analysis of the solar PV DC water pumping system. 2012. 3(7): p. 403-412.

3. Mousa, M., I.S. Ibrahim, and I.J.R.e. Molokhia, Comparative study in supplying electrical energy to small remote loads in Libya. 1998. 14(1-4): p. 135-140.

4. Al-Jadi, I.S.I., M. EKhlat, and N. Krema. Photovoltaic in Libya applications, and evaluation. in Proceedings of the InternationalConference on Renewable Energy for Developing Countries. 2005.

5. Shebani, M.M. and T.J.J.o.R.E. Iqbal, Dynamic Modeling, Control, and Analysis of a Solar Water Pumping System for Libya. 2017. 2017.

6. Tiwari, A.K. and V.R.J.R.E. Kalamkar, Effects of total head and solar radiation on the performance of solar water pumping system. 2018. 118: p. 919-927.

7. Khalil, A. and A. Asheibe. The chances and challenges for renewable energy in Libya. in the Proceedings of the Renewable Energy Conference. 2015.

8. Green, M.A.J.P.P., MA Green, K. Emery, Y. Hishikawa, W. Warta, and ED Dunlop, Solar cell efficiency tables (Version 45), Prog. Photovoltaics 23, 1 (2015). 2015. 23: p. 1.

9. Khatib, T.J.J.o.a.s., Deign of Photovoltaic Water Pumping Systems at Minimum. 2010. 10(22): p. 27732784.

10. Kumar, M., F. Ansari, and A. Jha, Efficient Generation of Electricity by Photovoltic Systems for Water Pumping in Rural Areas.

11. Ramelli, R., et al. International Symposium on Solar Physics and Solar Eclipses. in Solar Physics and Solar Eclipses (SPSE 2006). 2006.

12. Marsh, L.S., Pumping water from remote locations for livestock watering. 2009.

13. S. Chandel, M.N.N., and R. Chandel, , Review of solar photovoltaic water pumping system technology for irrigation and community drinking water supplies.
Renewable and Sustainable Energy Reviews, 2015. 49: p. 1084-1099.

14. Treephak, K., et al., An economic evaluation comparison of solar water pumping system with engine pumping system for rice cultivation. 2015. 54(8S1): p. 08KH01.

15. Odeh, I., Y. Yohanis, and B.J.S.e. Norton, Influence of pumping head, insolation and PV array size on PV water pumping system performance. 2006. 80(1): p. 51-64.

16. Hamza, A.A. and A.Z.J.R.e. Taha, Performance of submersible PV solar pumping systems under conditions in the Sudan. 1995. 6(5-6): p. 491-495.

17. Ghoneim, A.J.E.c. and management, Design optimization of photovoltaic powered water pumping systems. 2006. 47(11-12): p. 1449-1463.

18. Chilundo, R.J., et al., Design and Performance of Photovoltaic Water Pumping Systems: Comprehensive Review towards a Renewable Strategy for Mozambique. 2018. 6(07): p. 32.

19. Kyaing, N.S.Y. and W. Swe, Design Considerations of PV Water Pumping and Rural Electricity System (2011) in Lower Myanmar.

20. Mohamed, A.O., A.J.J.o.B. Hasan, and a.s. Research, Effect of dust accumulation on performance of photovoltaic solar modules in Sahara environment. 2012. 2(11): p. 11030-11036.

21. Gouws, R. and T. Lukhwareni, Factors influencing the performance and efficiency of solar water pumping systems: A review. 2012.

22. Mohamed, A.M., A. Al-Habaibeh, and H.J.R.e. Abdo, An investigation into the current utilisation and prospective of renewable energy resources and technologies in Libya. 2013. 50: p. 732-740.

23. Ibrahim, I.S. and N. Kreama, PERFORMANCE AND EXPERIENCE OF STAND ALONE PV SYSTEMS USED TO ELECTRIFY AN ISOLATED VILLAGE IN LIBYA.

24. Jenkins, T., Solar-powered Water Pump Design Spreadsheet Version II: User Manual. 2014: New Mexico State University, Cooperative Extension Service, Engineering New

\section{Biographical notes}

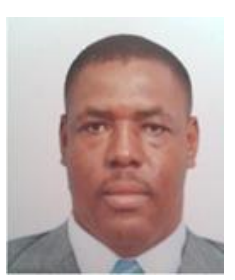

Ali Omar Maka received his M.Sc degree in Mechanical engineering from Cranfield University UK 2008. Current working as researcher in Arab Centre for Research and Development of Saharian Communities - Mourzuq, Libya. His scientific interests focus on renewable energy technology (solar PV and CPV technology) wind energy, also on heat transfer and gas turbine technology. He has participated in national research projects, therefore, presenting results of that work at international and national conferences. He published more than 6 scientific papers in international and national journals, and 5 conferences.

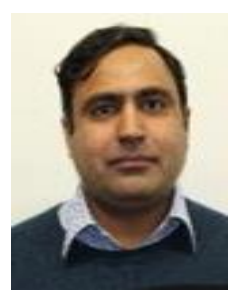

Dr. Tariq Nawaz Chaudhary I am an Assistant Professor in Mechanical Engineering Department of University of Engineering \& Technology, Lahore (Rachna Campus) Pakistan. I hold B.Sc and M.Sc Degrees in Mechanical Engineering from UET, Lahore and $\mathrm{PhD}$ from Heriot Watt University, UK. I am registered Professional Engineer and has more than 13 years of experience in teaching. I am author of 3 
research papers and supervised various projects to B.Sc students. My research is focused on fluid flow and heat transfer in fuel and solar cells. I have been awarded travel grant by electrochemical society USA and also won best poster prize.

Abdulazez HASAN received his M.Sc. degree in electrical engineering in 2017. Current working as researcher in Arab Centre for Research and Development of Saharian Communities - Mourzuq, Libya. His scientific interests focus on renewable energy technology (solar PV technology). He published 2 scientific journal papers and participated in 2 international conferences.

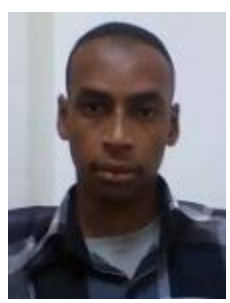

Ahmed GATOU received his B.Sc degree in electrical engineering in 2008. Current working as assistant researcher in Arab Centre for Research and Development of Saharian Communities - Mourzuq, Libya. He participated in 2 national conferences. 